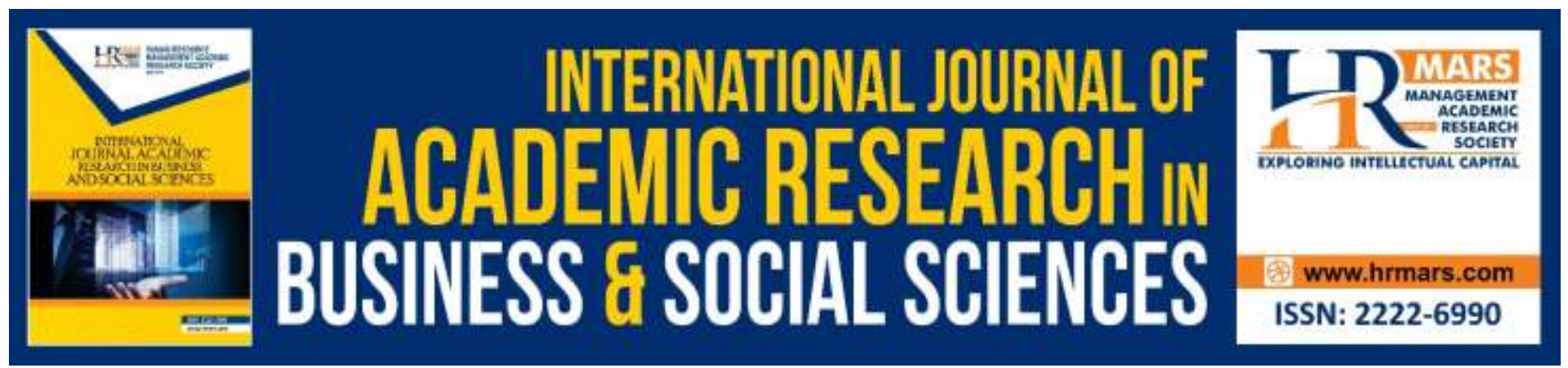

\title{
Development of Adolescent Anger Management Module Using Art Therapy
}

Shamshul Azura bin Md Yusof, Nor Shafrin binti Ahmad, and Rahimi Che Aman

To Link this Article: http://dx.doi.org/10.6007/JJARBSS/v10-i14/7357

DOI:10.6007/IJARBSS/v10-i14/7357

Received: 10 April 2020, Revised: 12 May 2020, Accepted: 10 June 2020

Published Online: 29 June 2020

In-Text Citation: (Yusof et al., 2020)

To Cite this Article: Yusof, S. A. bin M., Ahmad, N. S. binti, \& Aman, R. C. (2020). Development of Adolescent Anger Management Module Using Art Therapy. International Journal of Academic Research in Business and Social Sciences, 10(14), 1-10.

Copyright: (c) 2020 The Author(s)

Published by Human Resource Management Academic Research Society (www.hrmars.com)

This article is published under the Creative Commons Attribution (CC BY 4.0) license. Anyone may reproduce, distribute, translate and create derivative works of this article (for both commercial and non-commercial purposes), subject to full attribution to the original publication and authors. The full terms of this license may be seen at: http://creativecommons.org/licences/by/4.0/legalcode

Special Issue: WSTI2018 - Issues and Trends on Education, Science and Technology, 2020, Pg. 1 - 10 http://hrmars.com/index.php/pages/detail/IJARBSS JOURNAL HOMEPAGE

Full Terms \& Conditions of access and use can be found at http://hrmars.com/index.php/pages/detail/publication-ethics 


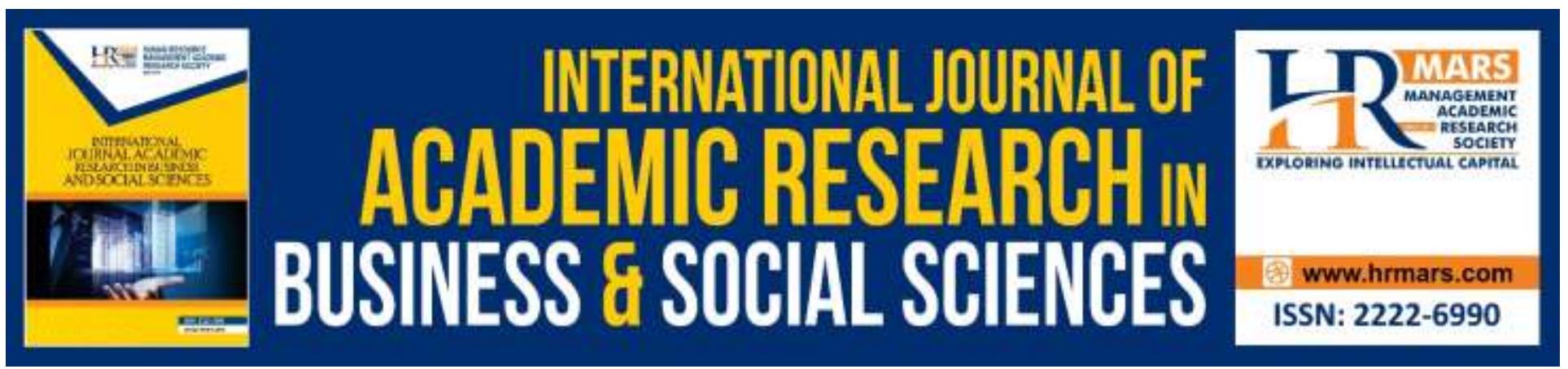

\title{
Development of Adolescent Anger Management Module Using Art Therapy
}

\section{Shamshul Azura bin Md Yusof, Nor Shafrin binti Ahmad, and Rahimi Che Aman}

School of Educational Studies, Universiti Sains Malaysia

Email: shamshulazura@gmail.com,sham@usm.my,rahimi@usm.my

\begin{abstract}
Normal for each individual to experience anger. Though uncontrolled anger is negative, when properly channelled, anger can bring positive outcomes. Thus, there is a need to develop an anger management module to help reduce the negative effects of anger among adolescents. This article discusses the construction of adolescents' anger management module by utilizing art therapy. Art therapy such as drawing allow an angry individual to channel their anger through their piece of drawing (Liebmann, 2004). Previous researches show that Art Therapy can reduce the intensity of anger. The development of this module involves several phases. In the first phase, a review of literature was carried out on issues related to anger among schooling adolescents and the approaches in managing anger. The second phase entailed discussions with experts in Art Therapy and experts in Counselling Psychology. Subsequently, in the third phase the Art Therapy Module was developed and tested. Based on comments from Art Therapy experts and Counselling and Psychology experts, this Module was pilot-tested before used in the actual field study. Based on literature reviews and discussions with experts, eight sessions that encapsulate eight modules were successfully developed. Module 1 focuses on orientation, relationship building and information on the ethics of group counselling. Module 2 includes aspects on anger identification, effects of anger and anger expression. Module 3 and 4 gives in-depth focus on the expression of anger. Meanwhile, Module 5 to 7 focus on the healing process to reduce adolescents anger intensity. Lastly, Module 8 contains the termination session. It is hoped that the development of this module can assist adolescents in managing their anger and consequently, reduce the number of discipline cases, which are related to anger issues.
\end{abstract}

Keywords: Module, Anger Management, Art Therapy, Adolescents.

\section{Introduction}

Anger can be defined as a sense of dissatisfaction due to injuries, persecution and opposition (Lochman, Barry, Powell \& Young, 2010). Individuals who are angry will usually show a desire to fight the cause of their anger. Similar views have also been put forward by Stemmler, Heldmann, Pauls, and Scherer (2001) who stated anger was an emotionally related psychological interpretation of 
someone who had been offended, persecuted, or denied his rights and that person was inclined to respond. Videbeck (2011), regarded anger as a normal emotion that feels uncomfortable and able to produces strong emotions in response to the cause of the anger. Gardner and Moore (2008), viewed anger as an internal feeling that has a negative psychological level, which contains cognitive and biological elements, and it changes frequently regardless of time.

There are various causes that can contribute to anger. Hughes, LaGreca, and Coneley (2001), stated that the feelings of anger and resentment among some children and adolescents are caused by broken families. This statement is also supported by Liebmann (2004) which stated that family problems are one of the contributors that give 'birth' to negative emotions such as anger among adolescents. In addition, parents who are often angry will also cause the children and adolescents to frequently show their anger. Apart from that, the feeling of dissatisfaction with a partner's behavior, children's attitudes, parents' behavior and colleagues' attitudes are correspondingly among the many causes of anger (Coles, Greene \& Braithwaite, 2002).

Negative and tragic consequences will often occur if the anger is not well-managed regardless of the cause (Gardner \& Moore, 2008). Social phobia, anxiety and depression are amongst the negative effects of anger (American Psychological Association (APA), 2008). According to APA (2008), 30 to 40 percent of victims with anxiety and depression are caused by anger. Based on findings in a study by Spielberger and Sarason (2013), anger can affect the physiology and biology of the individual. Physiological effects refer to a person's emotional changes such as the feeling of love which becomes hatred due to being angry. In fact, the level of anger can increase and can become more aggressive and violent. Relating to the biological effect, there will be an increase in the rate of the heartbeat, blood pressure, and an increase in adrenaline and noradrenaline which can have a harmful repercussion on health. According to Deffenbacher (2008), feelings of anger can escalate into something worse in which individuals tends to self-harm and do harm to others or even kill them.

Anger is often associated with negative emotions (Gardner \& Moore 2008), however according to Lerner and Tiedens (2006), anger will not always cause a person to act negatively. On the contrary, anger can help an individual to control a situation, to be more optimistic and readier to take risks Furthermore, being angry is better than being afraid because fear will cause a person to panic and unable to control the situation. Generally, anger will cause more negative effects (Gardner \& Moore 2008). Due to that, intervention will need to be planned in order to deal with anger issues. The development of adolescent anger management module using art therapy is an effort in managing anger issues specifically among adolescents.

\section{Research Methodology \\ Research Subjects}

This study is an early stage in developing adolescent anger management module. The respondents are those who are experts in the fields that are related to the module. They consisted of three experts in the field of art therapy and three who specialize in psychological counseling. Listed below is the list of specialists who participated in this study and their area of expertise. 
INTERNATIONAL JOURNAL OF ACADEMIC RESEARCH IN BUSINESS AND SOCIAL SCIENCES

Vol. 10, No. 14, Special Issue: WSTI2018 - Issues and Trends on Education, Science and Technology, 2020, E-ISSN: 2222-6990 @ 2020 HRMARS

Table 1: The list of specialists who participated in this study and their area of expertise.

\begin{tabular}{lll}
\hline Individual & Institutions/Places & Specialities \\
\hline 1. & Universiti Putra Malaysia & $\begin{array}{l}\text { (Associate Professor) } \\
\text { Ph.D., Guidance \& Counselling, } \\
\end{array}$ \\
& & Module Construction \\
\hline 2. & Universiti Utara Malaysia & (Associate Professor) \\
& & Psychology Counselling \\
& & Expressive Art Therapy \\
\hline 3. & Universiti Sains Malaysia & Ph.D., Guidance \& Counselling \\
& & - Trauma \& Anger Management \\
\hline 4. & Universiti Utara Malaysia & Ph.D., Creative Art Therapy (CAT) \\
5. & Universiti Utara Malaysia & Ph.D., Guidance \& Counselling \\
\hline 6. & Cheras, Kuala Lumpur & - Registered Art Therapist \\
& & -Associate Membership Australian \& New \\
& & Zealand Art Therapy Association (ANZATA) \\
\hline
\end{tabular}

\section{Research Procedures}

This research is divided into three (3) phases. The first phase was the literature study pertaining to issues of anger among adolescents in schools as well as the approach in managing the anger. The second phase consisted of a discussion among the six experts on art therapy and psychological counselling. The third phase was the initial development of the module and testing the validity.

The first procedure in module development was to determine the objective of the modules. For these modules, five objectives have been determined and it is aimed that all of the adolescents or students will achieve the objectives by the end of each module activities. The first objective is to understand the concept of anger, second objective is knowing the cause of their anger, the third objective is enabling them to express their anger through art therapy activities, the fourth objective is they are able to control and ease their level of anger and the fifth objective is they are able to use art therapy activities as a way to manage their anger. Apart from establishing the general objectives, various specific objectives have also been set for each of the eight modules.

The next process was analyzing the anger among adolescents or students. This process was used to identify the target group that would be able to follow the module. The target group would be adolescents who experience anger management problems. The next process was sorting the module based on the order and through material selection. The selection of materials for this module is based on the expert recommendations and references related to art therapy. This process went to some changes in response to the feedback from experts and after a pilot study.

\section{Research Tools}

The tool used for this study was the content validity module questionnaire (Soal Selidik Kesahan Kandungan Modul) by Ahmad (2012). This questionnaire was developed specifically to test the content validity of the modules, including the modules on teaching, motivations, psychological counseling or academic counseling (Ahmad, 2012). This questionnaire used the Likert scale responses and it included the content based on the expert's opinions of the module. This form must also be 
signed and validated with official confirmation of the position and dated by the expert in validating the module.

\section{Research Results}

The first phase of the research found that anger issues among adolescents is a very serious issue and need to be addressed (Golden, 2006). According to Golden (2006), angry adolescents are often involved in cases of misconduct and crime. This statement is supported by Norisham (2013) who stated that there are adolescents in Malaysia who are intentionally or unintentionally involved in misconduct and crime when they are angry. According to Norisham (2013), there are juvenile and criminal cases committed by adolescents in Malaysia due to their uncontrollable anger. For these reasons, Golden (2006) recommended that these young adults needed to be helped, supported, and they needed to be educated on the coping skills and ways to control their anger. In fact, according to Golden (2006), the importance of adolescents knowing how to deal with anger is just as important as learning academic subjects. In regard to anger management, a literature review found that, anger experts such as Kassinove and Tafrate (2002), preferred to use approaches in using therapy such as Cognitive Behavioural Therapy (CBT). Breiner, Tuomisto, Bouyea, Gussak, and Aufderheide (2012) also stated that approaches such as Psychodynamics, CBT and Rational Emotive Behavioural Therapy (REBT) are more prevalently used by psychologists and counsellors in handling cases related to anger issues. Similar findings were also stated by Norisham (2013). His survey on four schools and three institutions of teaching in Kuala Lumpur and Selangor founds that the counsellors at the institutions used CBT and REBT approaches in managing cases which involved adolescents' anger issues.

However, Breiner et al. (2012) strongly encouraged the use of art therapy, dance therapy and music therapy in the management of mental health, emotion, and physical health. According to Breiner et al. (2012), through art therapy, an individual will unconsciously get to learn more about him/herself from various point of view which he did not aware previously. For Liebmann (2004), art therapy can reduce the level of anger in a client. According to Liebmann (2004), when an angry client draws on paper, the anger can be dismissed even though the client was silent. However, in Malaysia, studies on the use of art therapy as an approach in managing adolescents' anger are still limited. Therefore, this study was conducted in order to develop a module that uses art therapy as a way to manage anger issues among adolescents.

The second phase which was the discussion phase, involving the experts in art therapy and the field of psychological counselling. It was found that the experts had given constructive ideas and insights to the development of the modules. In summary, the experts suggested that the modules should be divided into four sections according to the theme as shown in Table 2.

Table 2: Module themes classification

\begin{tabular}{lcccc}
\hline Module Themes & Part 1 & Part 2 & Part 3 & Part 4 \\
\hline $\begin{array}{l}\text { Starting module } \\
\text { (Introductory) }\end{array}$ & $\begin{array}{c}\text { Anger } \\
\text { Expression } \\
\text { Module }\end{array}$ & $\begin{array}{c}\text { Healing module } \\
\text { (healing process) }\end{array}$ & $\begin{array}{c}\text { Finishing } \\
\text { Module }\end{array}$ \\
\hline Order to be developed & 1 & 3 & 3 & 1 \\
\hline
\end{tabular}


According to Jamaludin Ahmad (2012), the development of a new module, should be based on modules construction models. After the discussion with the module experts, he suggested that this module should be developed based on Russel Model (Russel, 1974). This model has outlined the eight essential elements of developing a new module. The elements consist of determining the objectives of the module, analysis of the students, the process of using the module on the students, to arrange the module according to their order and to select the appropriate materials such as crayon or color pencil to determine the validity of the module and to determine the reliability of the module. Below are the results of the first and second phases; thus in the third phase, eight modules have been developed as follows:

Table 3: Content of Module

1. Module 1 (Session 1): Themes (Intro / Icebreaking

Name of activity: $\quad$ My favorite animal.

Duration: $\quad 1$ to 2 hours.

Materials: $\quad$ Painting paper and crayons

Methods: Briefing, drawing and discussion

Objectives: $\quad$ At the end of the session, students will be able to:

1. Explain on group ethics.

2. Knowing friends in the group.

3. Being friendly with all the friends in the group

2. Module 2 (Session 2): Themes (Anger Expression)

Name of activity: My anger

Duration: $\quad 1$ to 2 hours

Materials: $\quad$ Pamphlet (Knowing your anger), A4 paper, marker pen, drawing paper, and crayons.

Methods: $\quad$ Briefing, drawing and discussion

Objectives: $\quad$ At the end of the session, students will be able to:

1. Explain the definition of anger.

2. Explain the effects of anger.

3. Expressing anger in a way of drawing

3. Module 3 (Session 3): Themes (Anger Expression)

Name of activity: I'm The Volcano

Duration:

1 to 2 hours

Materials:

Painting paper and crayons.

Methods: Drawing and discussion

Objectives:

At the end of the session, students will be able to:

1. Draw a volcano.

2. Explain the meaning of the drawing.

3. Expressing anger emotion through drawing

4. Module 4 (Session 4): Themes (Expressing anger)

Name of activity: Uli-uli and Picit-picit 


\section{Duration: $\quad 1$ to 2 hours \\ Materials: $\quad$ Plasticine and drawing paper}

Methods: $\quad$ To shape plasticine and discussion

Objectives: $\quad$ At the end of the session the student will be able to:

1. Produce plasticine forms related to angry emotions.

2. Explain the meaning of the forms that were produced

3. Expressing anger emotion.

5. Module 5 (Session 5): Theme ( Healing Process)

Name of activity: Smile on My Face.

Duration: $\quad 1$ to 2 hours

Materials: $\quad$ A4 paper or drawing paper, color crayons, pencil color and water color.

Methods: Drawing and discussion

Objectives: $\quad$ At the end of the session, students will be able to:

1. Produce paintings based on the smile of my face.

2. Explain the meaning of the drawing.

3. Explain the goodness of the smiling.

6. Module 6 (Session 6): Theme ( Healing process)

Name of activity: Tranquility

Duration: $\quad 1$ to 2 hours.

Materials: $\quad$ Color paper, glue, scissors, A4 paper and pencils.

Methods: Drawing and discussion.

Objectives: $\quad$ At the end of the session, students will be able to:

1. Produce a collage with tranquillity as the theme.

2. Share stories based on the created collages.

3. Explain the importance of having peace in life.

7. Module 7 (Session 7): Theme (Healing process)

Name of activity: My dream

Duration: $\quad 1$ to 2 hours.

Materials: $\quad$ Drawing paper or A4 paper, watercolor and brush.

Methods: Drawing and discussion.

Objectives: $\quad$ At the end of the session, students will be able to:

1. Produce painting based on the theme 'My Dream'

2. Explain the meaning of the drawing

3. Explain the types of emotions that are needed to achieve

one's dreams.

8. $\quad$ Module 8 (Session 8): Theme (Healing process)

Duration: $\quad 1$ to 2 hours

Materials: $\quad$ Painting paper, crayons, and water color.

Methods: Drawing and discussion.

Objectives: $\quad$ At the end of the session, students will be able to: 
1. Produce painting based on the theme 'experience'.

2. Explain the meaning of the drawing.

3. Explain the benefits gained throughout their participation in the module.

The result of the validity of the module contents are as follows:

Table 4: Expert score on the level of content validity

\begin{tabular}{|c|c|c|c|c|c|c|c|c|}
\hline & \multirow{2}{*}{ Statements } & \multicolumn{7}{|c|}{ Expert Score } \\
\hline & & 1 & 2 & 3 & 4 & 5 & 6 & 7 \\
\hline 1. & $\begin{array}{l}\text { The content of this module suits its target } \\
\text { population }\end{array}$ & 5 & 4 & 4 & 4 & 4 & 4 & 4 \\
\hline 2. & $\begin{array}{l}\text { The content of this module can be perfectly } \\
\text { executed }\end{array}$ & 4 & 4 & 4 & 4 & 4 & 3 & 4 \\
\hline 3. & $\begin{array}{l}\text { The content of this module is suitable for the time } \\
\text { that was allocated. }\end{array}$ & 4 & 4 & 4 & 4 & 3 & 4 & 4 \\
\hline 4. & $\begin{array}{l}\text { The content of this module can help adolescents or } \\
\text { students in reducing their level of anger through art } \\
\text { therapy. }\end{array}$ & 5 & 4 & 4 & 4 & 4 & 4 & 5 \\
\hline 5. & $\begin{array}{l}\text { The content of this module can help adolescents or } \\
\text { students in managing their anger towards a better } \\
\text { and positive change in their behaviour. }\end{array}$ & 5 & 4 & 4 & 5 & 4 & 4 & 5 \\
\hline & Total expert score & 23 & 20 & 20 & 21 & 19 & 19 & 22 \\
\hline & $\frac{(\text { Total expert score) }}{25} \times 100=$ & 92 & 80 & 80 & 84 & 76 & 76 & 88 \\
\hline
\end{tabular}

*Expert score value on content validity

5 = Strongly Agree ,4 = Agree, 3 = Neither Agree nor Disagree, 2 = Disagree,

$1=$ Strongly Disagree

According to Tuckman and Waheed (1981) and Abu Bakar Nordin (1995), as the level of validity is at $70 \%$ or more, it can be assumed that the module is a success or had achieved a high level of attainment. Due to that, the validity score of the module given by the expert is calculated by its percentage value using the following percentage;

$\underline{\text { Total expert score }} \times 100 \%=$ Level of control of content validity

Maximum score

Figure 1: Content Validity Mastery level formula

According to Jamaludin Ahmad (2012), the modules with a degree of validity of over $70 \%$ content are modules with good content validity. Based on all the percentages of scores given by the experts, this module can be considered to have good content validity. 


\section{Discussions}

In building a new module, the process needs to be guided by a model on module construction. This module was built based on Russel Model (Russel, 1974). This module has also accomplished certain processes as outlined in the module construction model. These processes will always experience a repeat in up and down with the purpose of purifying and improving the module until it reaches a high level of content validity (Ahmad, 2012).

\section{Implications of the Study}

This study can expand the knowledge especially in the construction of new modules related to anger and art therapy. This study also helps to understand the processes and elements needed in building a new module. Knowledge in the development of new modules will allow other researchers to develop other modules in the field of psychological counselling. Furthermore, the addition of this module will expand the field of psychological counselling in providing helpful services.

\section{Limitation of the Study}

This study only discussed the aspect of developing a module. The model that was used as a guide was the Russel Model (Russel, 1974). Since this module is still in the process of determining the reliability of the module, the findings regarding the reliability of this module are not discussed yet.

\section{Conclusion}

This adolescent anger management module is expected to be a great help in managing adolescent's anger so as to reduce the percentage of adolescent's discipline problems arising from anger management issues.

\section{References}

American Psychological Association. (2008), Controlling anger-before it controls you, Washington D.C.

Nordin, Abu B. (1995), Penilaian Afektif, Kajang: Masa Enterprise.

Breiner, M. J., Tuomisto, L., Bouyea, E., Gussak, D. E., \& Aufderheide, D. (2012). Creating an art therapy anger management protocol for male inmates through a collaborative relationship, International Journal of Offender Therapy and Comparative Criminology, 56(7), 1124-1143.

Coles, C. J., Greene, A. F., \& Braithwaite, H. O. (2002). The relationship between personality, anger expression, and perceived family control among incarcerated male juveniles, Adolescence, 37, 395-409.

Deffenbacher, J. L. (2011). Cognitive-behavioral conceptualization and treatment of anger. Cognitive and Behavioral Practice, 18(2), 212-221.

Golden, B. (2006). Healthy anger: How to help children and teens manage their anger. USA. Oxford University Press.

Gardner, F. L., \& Moore, Z. E. (2008). Understanding Clinical Anger and Violence: The Anger Avoidance Model. Behavior Modification, 32(6), 897-912.

Hughes, J. N., La Greca, A. M., \& Coneley, J. C. (2001). Handbook of psychological service for children and adolescent. New York. Oxford University Press.

Ahmad, J. (2012). Modul \& Pengendalian Bimbingan Kelompok. Serdang. UPM. 
Kassinove, H., \& Tafrate, R. C. (2002). Anger management: The complete treatment guidebook for practitioners. Impact Publishers.

Lerner, J. S., \& Tiedens, L. Z. (2006). Portrait of the angry decision maker: How appraisal tendencies shape anger's influence on cognition, Journal of Behavioral Decision Making (Special Issue on Emotion and Decision Making), 19, 115-137.

Liebmann, M. (2004). Art therapy for groups: A handbook of themes and exercises. Psychology Press.

Lochman, J. E., Barry, T., Powell, N., \& Young, L. (2010). Anger and aggression. In Practitioner's guide to empirically based measures of social skills. New York. Springer.

Abdul Ghani, N. (2013). Senario Kemarahan Remaja: Satu Tinjaun Umum Di Sekolah-sekolah Menengah Negeri Selangor. Jurnal Psikologi Dan Kaunseling. Bil 4. 39-57. Kementerian Pelajaran Malaysia.

Russel, J. D. (1974). Modular Instruction: A Guide to Design, Selection, Utilization and Evaluation of Modular Material. New York. Publishing Company.

Spielberger, C. D., \& Sarason, I. G. (2013). Stress and emotion: Anxiety, anger, \& curiosity. Taylor \& Francis.

Stemmler, G., Heldmann, M., Pauls, C. A., \& Scherer, T. (2001). Constraints for emotion specificity in fear and anger: The context counts. Psychophysiology, 38(2), 275-291.

Tuckman, B. W., \& Waheed, M. A. (1981). Evaluating an individualized science program for community college students. Journal of Research In Science Teaching, 18(6), 489-495.

Videbeck, S. L. (2011). Psychiatric-Mental Health Nursing. Fifth Edition. Philadelphia. Wolters Kluwer Health. 